\title{
Leisure Activities for Patients with Diffuse Connective Tissue Diseases
}

\author{
Marielle Fornazzaro Nascimento, Paulo Eduardo Neves Ferreira Velho, \\ Raphaela Espanha Corrêa, and Rute Estanislava Tolocka
}

\section{ABSTRACT}

Leisure is everyone right, regardless of the clinical condition of each individual. The quality of life (QoL) of patients with dermatoses has been related to the practice of leisure activities (PLA); however, little is known about this practice in these patients. This study aimed to verify the PLA in patients with Diffuse Connective Tissue Diseases (DCTD). This is a descriptive, qualitative, and quantitative field study with patients seen at the Dermatology Outpatient Clinic (Hospital de Clínicas) of the University of Campinas (UNICAMP), São Paulo, Brazil. A form was used, containing closed questions about the sociodemographic and clinical profiles, and an open question about leisure. The responses were categorized according to the classification of leisure cultural content. Descriptive statistics, construction of a crosstable and the Mann-Whitney and Kruskal-Wallis tests were used. Data from 62 patients were collected, who aged between 19.4 and 75.3 years (average of $49.32 \pm 12.55$ years). Among the patients, 80.6\% were female and $70.9 \%$ were diagnosed with Cutaneous or Systemic Lupus Erythematosus (LE). The most practiced leisure activities were those related to manual and virtual content, mentioned by $24.6 \%$ of the patients. Another $18.0 \%$ reported preferring to stay at home or sleep (other activities), and no patient reported physical-sports or tourist leisure practices. The PLAs were little varied, showing $\mathbf{7 5 . 8 \%}$ of the patients taking only one type of content related to these practices and $12.9 \%$ not carrying out any leisure activities. The elderly were the ones who most reported manual and virtual activities. An association was found between the variety of leisure content practiced and literacy level. Illiterate patients were those who least reported activities related to leisure, when compared to those who completed elementary school $\left(X^{2}=24.686 ; p=0.035\right)$. Before diagnosis, $56.5 \%$ of the patients performed physical activities, of which 27.4\% could be classified as physical-sports leisure. After the disease development, only $19.7 \%$ of them maintained physical activities, and, of all the activities practiced by them, only $9.7 \%$ could be considered as leisure activities, but none as physical-sports leisure. Thus, it appears that leisure practices among patients with DCTD are scarce and little varied, which interferes with their QoL. The orientation and practice of these activities are necessary so that they can make choices and vary the types of activities practiced. Likewise, more studies, which can support actions that encourage and enable the leisure practices of these patients, play an important role.

Keywords: Autoimmune Diseases, Connective Tissue, Leisure Activities, Physical Activities.

\section{INTRODUCTION}

Leisure is a right of all individuals as expressed in Article XXIV of the Universal Declaration of Human Rights: "Every human being has the right to rest and leisure" [1] and the same is ensured by the Constitution of the Federative Republic of Brazil, in its 6th Article in Chapter II [2].

This means that, regardless of social or clinical condition, everyone has the right to leisure. However, the fulfillment of this right is not always feasible, and, in many cases, it can even be made difficult. For example, Finlay e Khan [3] showed that patients with dermatoses had difficulties in accessing leisure and this could be one of the aspects related
Submitted : May 12, 2021

Published : June 10, 2021

ISSN: $2593-8339$

DOI: $10.24018 /$ ejmed.2021.3.3.875

\section{F. Nascimento}

Faculty of Physical Education, Methodist University of Piracicaba - UNIMEP, Piracicaba, SP, Brazil.

(e-mail: marielle.camille@ hotmail.com) P. E. N. F. Velho

Faculty of Medical Sciences - FCM, University of Campinas - UNICAMP, Campinas, SP, Brazil.

(e-mail: pvelho@unicamp.br)

R. E. Corrêa

Faculty of Medical Sciences - FCM, University of Campinas - UNICAMP, Campinas, SP, Brazil.

(e-mail: raphaespanha@yahoo.com.br) R. E. Tolocka*

Human Movement Sciences Graduate Program, Methodist University of Piracicaba - UNIMEP, Piracicaba, SP, Brazil.

(e-mail: nupemlab@ gmail.com)

*Corresponding Author to the reduction in their quality of life $(\mathrm{QoL})$. Among these difficulties, limitations for outdoor activities were reported, either because of photoexposure or prejudice caused by visible changes in their skin. This study culminated in the creation of a specific questionnaire on the QoL of people with dermatological diseases: The Dermatology Life Quality Index (DLQI), which has been widely used in studies on QoL and dermatological diseases [4]-[6].

In the beginning, specific DLQI scores were presented and QoL and leisure relationships were explained in the case of patients with skin diseases. Among them, the most affected domains were leisure and daily activities in patients with psoriasis [7] and vitiligo [8]. 
Although some studies recognize the damage to the QoL of these patients, according to Finlay [9], considering leisure as an important element in the QoL of people with skin diseases, most studies using DLQI are limited to mentioning that there are losses, without further investigating leisure practices. Examples are the studies about patients with psoriasis, by Mattei et al. [6] and Langenbruch et al. [10], or related to patients with rosacea, by Mohta et al. [11].

This also occurs among studies using DLQI [12]-[14] on patients with DCTD, previously known as "collagen diseases," which are a group of diseases resulting from persistent and immune-mediated inflammation [15]. Such studies predominantly point out associations between characteristics of some of these diseases and general QoL scores, without bringing the scores of the different DLQI items. Therefore, although these studies find results on characteristics of the disease that can hinder the leisure practice, they do not even mention this theme.

Thus, there are studies on QoL in patients with Discoid Lupus Erythematosus and Systemic Lupus Erythematous (SLE) [12]; LE described as specific, non-specific and both [13] and Cutaneous LE [14]. These studies refer to clinical types, pain and the visibility of injuries related to loss of QoL.

Although these are factors mentioned by Finlay [3], [9], as aspects that hinder the practice of sports and leisure activities and there are specific DLQI categories on leisure in general and on physical activities, there are no references to this theme in the studies about DCTD. There are studies about dermatomyositis (DM) and QoL that used DLQI and the disease severity index (Cutaneous Dermatomyositis Disease Area and Severity Index Activity - CDASI-A), which is a consensus measure, established to assess activity and damage of this disease. The increase in the area affected by DM decreases the DLQI in adult patients with the disease [16], [17], but these studies do not show results of the different domains that make up the DLQI, failing to specify the relationships between the items on leisure and the other variables analyzed.

Among studies on QoL are also those that analyze different variables, such as disease impact indexes (Skindex-16 or Skindex-29), global assessment of the disease by doctors and other instruments for collecting QoL data other than the DLQI. Similarly, in these studies, results were not presented by specific scores of the items contained in the instruments for assessing QoL, although variables such as pruritus, related to leisure, have been identified [18], [19].

Finlay [9] also pointed out that the QoL of patients with skin diseases can be impaired in relation to sports activities due to their skin conditions, because they are also concerned with what other people may think about their appearance. Studies like the one by Kim et al. [20] emphasize that patients with LE are little engaged in physical activities. Margiotta et al. [21] found that such patients have shown sedentary behavior. Thus, physical-sports leisure may also be impaired, but studies that specifically analyze this type of leisure have not been found in patients with DCTD.

Although Finlay [9], in a review on the use of DLQI, stated that this questionnaire should be used to verify aspects that were impaired in patients' lives in order to define appropriate protocols for therapies, it is clear that this concern has not been considered when it comes to collecting data to support actions that encourage and enable the leisure practice of these patients.

Because of this gap, it is found as difficult the formulation of protocols that assist in reducing the difficulties encountered in QoL related to leisure practice, even though studies continue to point out directly or indirectly a correlation between leisure and impairment in QoL.

Among the reasons that may be related to the scarcity of studies on leisure practices among dermatological patients is the utilitarian view of leisure, which seeks reasons to validate the universal right to leisure to some other benefit, since the existing studies on QoL in dermatological patients are not concerned with welcoming complaints about the difficulties in leisure practice that such patients may have.

However, the leisure experience in itself must constitute a desired benefit, which is closely related to the human being's QoL.

Authors of renowned studies on leisure oppose it to work. For example, Dumazedier [22] considered leisure as a set of occupations practiced by people of their own free will, as long as there are no professional, family or social obligations, which compromise this time. Requixa [23] pointed leisure as a non-mandatory activity that provides a psychosomatic recovery, personal and social development.

It is also necessary to note that these positions are controversial because, as mentioned by Silva et al. [24], conceiving leisure as a time free of obligations addresses it as a residual time, that is, small lapses of time related to the workday, aiming at improvements in production rates at work, instead of observing it as an important practice in itself.

This relationship between leisure and work has its implications for the health field, where the professionals involved in the care are often seen as someone having the mission of taking care of someone's body, in their fight against diseases, which reduces the notion of what health really is, disregarding that the term refers to the individual's well-being and not just the absence of disease [25].

On the other hand, conceiving leisure as a right in itself addresses it as a cultural phenomenon, with different categories that still need to be better investigated so that the right to it can be guaranteed [26].

Therefore, there is a need of studies on leisure practices performed by patients with dermatological diseases, which can contribute to the understanding of the activities performed by them and are not only included in total scores. Thus, the aim of this study was to verify the leisure activity practices performed by patients with DCTD, characterized in terms of clinical and sociodemographic profiles, and search for associations that contribute to the formulation of actions that promote leisure practices that imply improvements in the QoL of these patients.

\section{MATERIALS AND METHOdS}

\section{A. Study Design and Population}

This is a descriptive and qualitative field research carried out at the Dermatology Outpatient Clinic (Hospital de Clínicas) of University of Campinas (UNICAMP), São Paulo, Brazil. Patients randomly chosen participated in the study. The criteria were: diagnosis of some type of DCTD, 
male or female, agreement on signing the Informed Consent Form (ICF). It is also important to say that patients under 18 or who did not complete the data were excluded.

\section{B. Approach}

Patients were approached while waiting for procedures at the outpatient clinic, and were called from their medical records, which were organized with a numeric password upon arrival at this facility. The invitation to participate in the study was made presenting the ICF and clarifying doubts that arose. Those who agreed to participate in the study answered the form, which contained questions about age, gender, diagnosis, time of diagnosis, comorbidities, and time of attendance at the Outpatient Clinic of UNICAMP Hospital. The information about the practice of physical leisure was collected through a question on physical activities performed before and after the disease onset, which is widely used in population surveys [27]: "what do you like to do in your free time?" The question enabled the generation of unanticipated data [28], [29] and was part of the method used for data collection for the creation of the DLQI [3]. The answers to the open question were analyzed by extracting the main categories of cultural leisure content [22], [30], [31], namely: artistic, physical-sports, intellectual, manual, social-tourist and virtual leisure.

Activities such as walking, relaxing, sleeping or staying at home have been classified as "others." Such responses were compared with the answers about physical activities practiced in free time, in order to check if, among them, there would be those considered as physical-sports leisure, according to the literature. For this study, the practice of sports or other supervised physical activities with scheduled times and on specific days were not considered as leisure activities, for leisure is related to free-of-obligation activities, according to the theoretical assumptions on the subject. In addition, walking was not included as physical-sports leisure because they are not sports activities [22], [23], [26].

\section{Statistical Treatment}

The sociodemographic and clinical profiles were analyzed using descriptive statistics regarding data distribution, with average calculation, standard deviation, relative and absolute frequency. The crosstable was applied between the sociodemographic and clinical variables in relation to the leisure content mentioned.

The Mann-Whitney and Kruskal-Wallis tests were used to verify the possible differences between groups of variables related to sociodemographic and clinical profiles and the variability of leisure practiced by patients. The calculations were made using Excel 2013 software and the Statistical Package for the Social Sciences (SPSS $®$ ), version 20.0, and the significance level adopted was $5 \%$.

The project was approved by the Research Ethics Committee of University of Campinas, with opinion No. $3,153,307$, in compliance with the rules of Ordinance 466/12 of the National Health Council. All patients signed the ICF.

\section{RESULTS}

Data were collected from 62 patients. Their age ranged from 19.4 to 75.3 years old (average age: $49.32 \pm 12.55$ ). The largest concentration of people were women in the age group of 18 to $45(80.6 \%)$, married $(41.9 \%)$ and had not completed elementary school $(37.1 \%)$. Regarding the diagnosis, most of the patients $(70.9 \%)$ were diagnosed with Cutaneous or Systemic LE and the others (29.1\%) with other DCTD.

The average time of diagnosis was $8.53 \pm 7.5$ years, while the average time of attendance in this clinic was $6.41 \pm 6.8$ years. Among the patients, $85.5 \%$ did not have a family member with the same disease, and $67.8 \%$ of them had comorbidities, as shown in Table I.

TABLE I: DISTRIBUTION OF THE PATIENTS' SOCIODEMOGRAPHIC AND

\begin{tabular}{|c|c|c|c|}
\hline Variable & Classification & (n) & $(\mathrm{n} \%)$ \\
\hline \multirow{3}{*}{ Age (yrs) } & $18-45$ & 25 & 40.3 \\
\hline & $46-60$ & 23 & 37.1 \\
\hline & Over 60 & 14 & 22.6 \\
\hline \multirow{2}{*}{ Gender } & Female & 50 & 80.6 \\
\hline & Male & 12 & 19.4 \\
\hline \multirow{5}{*}{ Education } & Illiterate & 3 & 4.8 \\
\hline & IES & 23 & 37.1 \\
\hline & CES & 17 & 27.4 \\
\hline & HS & 13 & 21.0 \\
\hline & HE & 6 & 9.7 \\
\hline \multirow{5}{*}{ Marital Status } & Single & 17 & 27.4 \\
\hline & Divorced & 11 & 17.8 \\
\hline & Married & 26 & 41.9 \\
\hline & Widowed & 3 & 4.8 \\
\hline & Common-law Marriage & 5 & 8.1 \\
\hline \multirow{6}{*}{ Diagnosis } & Cutaneous or Systemic LE & 44 & 70.9 \\
\hline & Scleroderma & 8 & 12.9 \\
\hline & Dermatomyositis & 4 & 6.5 \\
\hline & Sclerosing Panniculitis & 1 & 1.6 \\
\hline & Non-Lupus Vasculitis & 4 & 6.5 \\
\hline & Sneddon Syndrome & 1 & 1.6 \\
\hline \multirow{3}{*}{$\begin{array}{c}\text { Time since } \\
\text { diagnosis (yrs) }\end{array}$} & $<1$ & 10 & 16.1 \\
\hline & $1-10$ & 31 & 50.0 \\
\hline & $>10$ & 21 & 33.9 \\
\hline Outpatient & $<1$ & 15 & 24.2 \\
\hline attendance time & $1-10$ & 32 & 51.6 \\
\hline (yrs) & $>10$ & 15 & 24.2 \\
\hline \multirow{2}{*}{$\begin{array}{l}\text { Similar disease in } \\
\text { the family }\end{array}$} & Yes & 9 & 14.5 \\
\hline & No & 53 & 85.5 \\
\hline \multirow{2}{*}{ Surgery } & Yes & 38 & 61.3 \\
\hline & No & 24 & 38.7 \\
\hline \multirow{5}{*}{ Comorbidities } & None & 20 & 32.2 \\
\hline & One & 23 & 37.1 \\
\hline & Two & 14 & 22.6 \\
\hline & Three & 4 & 6.5 \\
\hline & Four & 1 & 1.6 \\
\hline
\end{tabular}

Key: IES= Incomplete Elementary School; CES= Complete Elementary School; HS = High School; HE $=$ Higher Education; LE $=$ Lupus Erythematosus.

Before the disease onset, $43.5 \%$ of the patients did not perform physical activities; $29.1 \%$ performed supervised activities such as dance, Pilates, zumba, yoga, swimming, weight training, basketball, gymnastics; and $27.4 \%$ practiced unsupervised activities, such as soccer, basketball, volleyball, cycling and walking. After the disease onset, only $19.4 \%$ of the patients maintained physical activities: $9.7 \%$ performing supervised programs (water aerobics, weight training, volleyball, jiu-jitsu and localized gymnastics) while the other 9.7\% performed walking without supervision. Regarding leisure practice, the most reported activities were manual and virtual content, reported by $24.6 \%$ of patients. Graph 1 illustrates the distribution of leisure activities reported in their respective categories, emphasizing that, because it is an open question, there was the possibility of mentioning more than one category. 


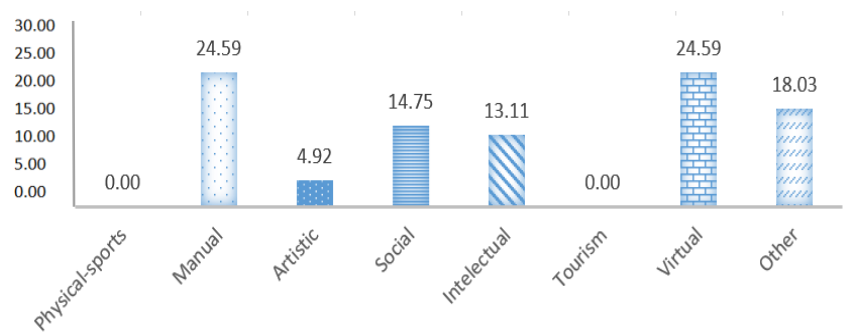

Fig. 1. Relative distribution of leisure activities by content practiced by patients.

Regarding the distribution of leisure variability, $12.9 \%$ did not report engaging in leisure practices; $75.8 \%$ reported leisure content, and $11.3 \%$ reported practicing two leisurerelated content.

We observe that the variability of leisure content practiced by patients differs according to education level $\left(\mathrm{X}^{2}=11.796\right.$; $p=0.019)$. Such difference can be observed by the post-hoc test $\left(\mathrm{X}^{2}=24.686 ; p=0.035\right)$, where illiterate patients had a lower variability in leisure content when compared to those with complete elementary education.

The other variables of the sociodemographic and clinical profiles did not show significant differences. The results can be seen in Table II.

The crosstable revealed that women performed more manual activities (21\%); men performed more virtual activities $(6.5 \%)$, and elderly or married people also reported more manual activities $(11.3 \%)$. Those who did not have complete elementary school mentioned manual and virtual activities ( $8.1 \%$ each); those who completed elementary school reported manual activities $(9.7 \%)$; those who had high school reported more virtual activities $(8.1 \%)$; those with higher education reported intellectual activities (4.8\%); and most illiterate patients in this group do not perform leisure activities in their free time (3.2\%).

Regarding the clinical profile, Table IV shows the distribution of variables, in the different leisure categories practiced; there were no reports of physical-sports leisure.
TABLE II: DISTRIBUTION OF LEISURE VARIABILITY IN RELATION TO

\begin{tabular}{|c|c|c|c|c|c|}
\hline \multicolumn{2}{|c|}{ Variables } & \multirow{4}{*}{$\begin{array}{c}\overline{\mathbf{x}} \\
\text { Ranks }\end{array}$} & \multirow{3}{*}{$\frac{U}{223.00}$} & \multirow{3}{*}{$\frac{X^{2}}{-}$} & \multirow{3}{*}{$\begin{array}{c}\begin{array}{c}p- \\
\text { value }\end{array} \\
0.067\end{array}$} \\
\hline \multirow{2}{*}{ Gender } & Female & & & & \\
\hline & Male & & & & \\
\hline & $18-45$ & & & & \\
\hline \multirow[t]{2}{*}{ Age (yrs) } & $46-60$ & 31.96 & - & 0.223 & 0.895 \\
\hline & Over 60 & 30.00 & & & \\
\hline \multirow{5}{*}{ Marital Status } & Single & 28.74 & & & \\
\hline & Divorced & 32.00 & & & \\
\hline & Married & 31.92 & - & 1.707 & 0789 \\
\hline & Widowed & 31.83 & - & 1.707 & 0.189 \\
\hline & Common-law & 37.40 & & & \\
\hline \multirow{5}{*}{ Education } & Illiterate & 13.67 & & & \\
\hline & IES & 28.39 & & & \\
\hline & CES & 38.35 & - & 11.796 & $0.019 *$ \\
\hline & HS & 29.88 & & & \\
\hline & $\mathrm{HE}$ & 36.42 & & & \\
\hline \multirow{7}{*}{ Diagnosis } & $\begin{array}{l}\text { Cutaneous or } \\
\text { Systemic LE }\end{array}$ & 31.33 & & & \\
\hline & Scleroderma & 31.88 & & & \\
\hline & Dermatomyositis & 25.13 & & & \\
\hline & $\begin{array}{l}\text { Sclerosing } \\
\text { Panniculitis }\end{array}$ & 32.00 & - & 5.052 & 0.410 \\
\hline & Non-lupus & 3200 & & & \\
\hline & Vasculitis & 32.00 & & & \\
\hline & $\begin{array}{l}\text { Sneddon } \\
\text { Syndrome }\end{array}$ & 59.00 & & & \\
\hline \multirow{3}{*}{$\begin{array}{c}\text { Time since } \\
\text { diagnosis } \\
(y r s)\end{array}$} & $<1$ & 26.45 & & & \\
\hline & $1-10$ & 32.84 & - & 1.722 & 0.423 \\
\hline & $>10$ & 31.93 & & & \\
\hline \multirow{3}{*}{$\begin{array}{l}\text { Outpatient } \\
\text { attendance } \\
\text { time (yrs) }\end{array}$} & $<1$ & 26.43 & & & \\
\hline & $1-10$ & 31.95 & - & 3.526 & 0.172 \\
\hline & $>10$ & 35.60 & & & \\
\hline \multirow{2}{*}{$\begin{array}{c}\text { Similar } \\
\text { disease in the } \\
\text { family }\end{array}$} & Yes & 38.00 & & & \\
\hline & No & 30.40 & 180.00 & - & 0.119 \\
\hline \multirow{2}{*}{ Surgery } & Yes & 33.36 & \multirow{2}{*}{385.50} & \multirow{2}{*}{-} & \multirow{2}{*}{0.174} \\
\hline & No & 28.56 & & & \\
\hline \multirow{5}{*}{ Comorbidities } & None & 29.20 & & & \\
\hline & One & 34.30 & & & \\
\hline & Two & 30.00 & - & 1.750 & 0.782 \\
\hline & Three & 32.00 & & & \\
\hline & Four & 32.00 & & & \\
\hline
\end{tabular}

School; HS = High School; HE = Higher Education; LE = Lupus Erythematosus; $\overline{\mathrm{X}}=$ Average $\mathrm{X} 2=$ Chi-square; ${ }^{*}=\mathrm{p}<0.05$.

TABLE III: CROSSTABLE OF THE RELATIVE DISTRIBUTION OF LEISURE AND SOCIODEMOGRAPHIC PROFILE

\begin{tabular}{|c|c|c|c|c|c|c|c|c|c|}
\hline \multirow{2}{*}{\multicolumn{2}{|c|}{ Variables }} & \multicolumn{8}{|c|}{ Leisure Content } \\
\hline & & Manual & Artistic & Social & Intellectual & Virtual & Others & Don't do & Total \\
\hline \multirow{3}{*}{ Gender } & Female & 21.0 & 3.2 & $11.3 \%$ & 9.7 & 12.9 & 14.5 & 8.1 & 80.6 \\
\hline & Male & 1.6 & 0.0 & 1.6 & 1.6 & 6.5 & 1.6 & 6.5 & 19.4 \\
\hline & $18-45$ & 4.8 & 3.2 & 4.8 & 4.8 & 8.1 & 8.1 & 6.5 & 40.3 \\
\hline \multirow[t]{4}{*}{ Age (yrs) } & $46-60$ & 6.5 & 0.0 & 6.5 & 6.5 & 6.5 & 6.5 & 4.8 & 37.1 \\
\hline & Over 60 & 11.3 & 0.0 & 1.6 & 0.0 & 4.8 & 1.6 & 3.2 & 22.6 \\
\hline & Single & 1.6 & 0.0 & 6.5 & 6.5 & 6.5 & 1.6 & 4.8 & 27.4 \\
\hline & Divorced & 1.6 & 0.0 & 4.8 & 1.6 & 1.6 & 6.5 & 1.6 & 17.7 \\
\hline \multirow{4}{*}{ Marital Status } & Widowed & 3.2 & 0.0 & 0.0 & 0.0 & 0.0 & 0.0 & 1.6 & 4.8 \\
\hline & CLM & 1.6 & 0.0 & 0.0 & 1.6 & 1.6 & 3.2 & 0.0 & 8.1 \\
\hline & Illiterate & 1.6 & 0.0 & 0.0 & 0.0 & 0.0 & 0.0 & 3.2 & 4.8 \\
\hline & IES & 8.1 & 0.0 & 4.8 & 3.2 & 8.1 & 6.5 & 6.5 & 37.1 \\
\hline \multirow[t]{4}{*}{ Education } & CES & 9.7 & 1.6 & 4.8 & 1.6 & 1.6 & 8.1 & 0.0 & 27.4 \\
\hline & HS & 3.2 & 1.6 & 3.2 & 1.6 & 8.1 & 0.0 & 3.2 & 21.0 \\
\hline & $\mathrm{HE}$ & 0.0 & 0.0 & 0.0 & 4.8 & 1.6 & 1.6 & 1.6 & 9.7 \\
\hline & TOTAL & 22.6 & 3.2 & 12.9 & 11.3 & 19.4 & 16.1 & 14.5 & 100.0 \\
\hline
\end{tabular}

Key. CLM = Common-Law Marriage; IES = Incomplete Elementary School; CES = Complete Elementary School; HS = High School; HE = Higher Education. 
TABLE IV: CROSSTABLE OF THE RELATIVE DISTRIBUTION OF LEISURE AND CLINICAL PROFILE

\begin{tabular}{|c|c|c|c|c|c|c|c|c|c|}
\hline \multirow{2}{*}{\multicolumn{2}{|c|}{ Variables }} & \multicolumn{8}{|c|}{ Leisure Content } \\
\hline & & \multirow{2}{*}{$\begin{array}{c}\text { Manual } \\
17.7\end{array}$} & \multirow{2}{*}{$\begin{array}{c}\text { Artistic } \\
1.6\end{array}$} & \multirow{2}{*}{$\begin{array}{c}\text { Social } \\
9.7\end{array}$} & \multirow{2}{*}{$\begin{array}{c}\text { Intellectual } \\
6.5\end{array}$} & \multirow{2}{*}{$\begin{array}{c}\text { Virtual } \\
12.9\end{array}$} & \multirow{2}{*}{$\begin{array}{c}\text { Others } \\
14.5\end{array}$} & \multirow{2}{*}{$\begin{array}{c}\text { Don't do } \\
8.1\end{array}$} & \multirow{2}{*}{$\begin{array}{l}\text { Total } \\
70.9\end{array}$} \\
\hline & $\begin{array}{l}\text { Cutaneous or } \\
\text { Systemic LE }\end{array}$ & & & & & & & & \\
\hline & Scleroderma & 1.6 & 0.0 & 0.0 & 4.8 & 3.2 & 0.0 & 3.2 & 12.9 \\
\hline \multirow[t]{4}{*}{ Diagnosis } & DM & 1.6 & 0.0 & 3.2 & 0.0 & 0.0 & 0.0 & 1.6 & 6.5 \\
\hline & S.Panniculitis & 0.0 & 0.0 & 0.0 & 0.0 & 0.0 & 0.0 & 1.6 & 1.6 \\
\hline & NL Vasculitis & 0.0 & 1.6 & 0.0 & 0.0 & 3.2 & 1.6 & 0.0 & 6.5 \\
\hline & Sneddon Syndrome & 1.6 & 0.0 & 0.0 & 0.0 & 0.0 & 0.0 & 0.0 & 1.6 \\
\hline \multirow{2}{*}{$\begin{array}{c}\text { Similar disease in } \\
\text { the family }\end{array}$} & No & 17.7 & 1.6 & 11.3 & 8.1 & 17.7 & 14.5 & 14.5 & 85.5 \\
\hline & Yes & 4.8 & 1.6 & 1.6 & 3.2 & 1.6 & 1.6 & 0.0 & 14.5 \\
\hline \multirow{4}{*}{ Surgery } & No & 1.6 & 1.6 & 3.2 & 3.2 & 14.5 & 9.7 & 4.8 & 38.7 \\
\hline & Yes & 21.0 & 1.6 & 9.7 & 8.1 & 4.8 & 6.5 & 9.7 & 61.3 \\
\hline & One & 9.7 & 3.2 & 8.1 & 6.5 & 4.8 & 1.6 & 3.2 & 37.1 \\
\hline & Two & 4.8 & 0.0 & 3.2 & 0.0 & 6.5 & 4.8 & 3.2 & 22.6 \\
\hline \multirow[t]{3}{*}{ Comorbidities } & Three & 3.2 & 0.0 & 1.6 & 0.0 & 1.6 & 0.0 & 0.0 & 6.5 \\
\hline & Four & 1.6 & 0.0 & 0.0 & 0.0 & 0.0 & 0.0 & 0.0 & 1.6 \\
\hline & None & 3.2 & 0.0 & 0.0 & 4.8 & 6.5 & 9.7 & 8.1 & 32.3 \\
\hline Time since & $<1$ & 1.6 & 0.0 & 1.6 & 0.0 & 1.6 & 6.5 & 4.8 & 16.1 \\
\hline diagnosis & $1-10$ & 9.7 & 3.2 & 8.1 & 6.5 & 12.9 & 6.5 & 3.2 & 50.0 \\
\hline (yrs) & $>10$ & 11.3 & 0.0 & 3.2 & 4.8 & 4.8 & 3.2 & 6.5 & 33.9 \\
\hline Outpatient & $<1$ & 3.2 & 0.0 & 3.2 & 0.0 & 4.8 & 4.8 & 8.1 & 24.2 \\
\hline attendance time & $1-10$ & 9.7 & 1.6 & 6.5 & 8.1 & 11.3 & 9.7 & 4.8 & 51.6 \\
\hline$(\mathrm{yrs})$ & $>10$ & 9.7 & 1.6 & 3.2 & 3.2 & 3.2 & 1.6 & 1.6 & 24.2 \\
\hline \multicolumn{2}{|c|}{ TOTAL } & 22.6 & 3.2 & 12.9 & 11.3 & 19.4 & 16.1 & 14.5 & 100.0 \\
\hline
\end{tabular}

Key: LE = Lupus Erythematosus; DM = Dermatomyositis; $\mathrm{S}=$ Sclerosing; NL = Non-Lupus.

\section{DisCUSSION}

In this study, based on the results verified in the crosstable, it is possible to observe how leisure practices took place in the studied group, in the different categories, according to different variables of the patients' profiles. Manual activities were mentioned more often by women, married people and the elderly; men reported more virtual activities as well as adults at the age of 18 to 45 .

To date, no studies have been found that analyze different categories of leisure practiced by people with DCTD. However, data from a study on leisure practice among Swedes can help understand the results found in our study. The referred study was conducted with four collections, over a 17-year period, observing subjects at the age (and over) 50, and with the combination of different models.

The Swedish study showed that social leisure activities decrease among men, but not among women. It also showed that in cognitive leisure activities (virtual and/or manual), the average prevalence increases between the ages of 50 and 70 , and decreases later, in both genders, with a higher prevalence among women; marital status did not significantly influence leisure practice. The same study showed that the clinical condition has an impact on leisure practice, that is, individuals with the highest number of diagnosed diseases are associated with sedentary social activities as the most mentioned leisure [32].

In our study, analyzing Table IV, it is noticeable that the proportion of patients who practiced leisure activities is higher among those who did not undergo surgery: those who did not undergo surgery performed such activities (15.8\%), whereas those who did $(12.4 \%)$. It is also observed that patients with no or only one comorbidity have greater leisure variability. Another observation is that the proportion of those who do not have leisure is higher among those who have had less than a year of diagnosis (almost 30\%), and among those who have more than ten years of diagnosis (almost 20\%). These data point to an influence of the clinical condition in leisure practice, either in the variability or in abstaining from this practice.

Regarding the education level, we observed in this study that the participants who had complete or incomplete elementary school and high school reported more manual and virtual activities, while those who had higher education mentioned intellectual activities more often, and illiterate patients said they did not practice any activities in their free time. These data corroborate the results of Finkel et al. [32], who pointed out a direct relationship between the level of education and participation in leisure activities and an inverse relationship regarding the decline in the participation of these activities according to the age.

Regardless of having or not comorbidities, we found that the activity expressed as pleasurable was only related to the practice of sedentary leisure. This can be explained by considering that the physical manifestations caused by the disease, such as clinical type, pain, and visibility of the lesion, affected area or symptoms of itching [12], [14], [16]-[19], [33] may limit the patients' physical willingness to perform leisure activities [3], [9], [16].

Symptoms such as fatigue, pain, loss of motor strength, depression, and body image disorders have already been described in patients with DCTD [34]-[38] and they hinder the performance of physical-sports leisure.

The data in Table IV also show the lack of opportunities and the distancing from the practices of the leisure physicalsports category among patients with DCTD when compared to the practice of these activities by the general population. The prevalence of physical-sports activities in the population in Brazil among males is $27 \%$ and, in females, $18.5 \%$, which are still insufficient rates. The same can be seen with populations in the Southeastern region, where proportions are close to those of the whole country's population $(27.1 \%$ and $19.2 \%$, respectively) [39], and in the city of São Paulo (20.3\% and $12.9 \%$, respectively) [27].

A factor that may have contributed to this is the low level of education of the patients who participated in the study, as $41.9 \%$ of them were illiterate or had not completed elementary school, and people with low education tend to 
decrease the practice of physical activity during leisure, compared to those with higher education [40], [39], [27], [32].

The observation of cross-data between reports about physical activities performed by patients and activities they like to do in their free time showed that, although there were no reports of activities that could be placed in the leisure physical-sports category after the disease diagnosis, one in four patients performed physical activities without supervision before the disease onset, such as soccer, basketball, volleyball, cycling, in addition to walking, which is a physical activity and not a sports activity. This indicates that there were leisure physical-sports activities, as these sports were performed in their free time and were not mandatory. After the disease, only $9.7 \%$ of patients perform non-supervised physical activities, but none practiced sports activities, as only walking was reported.

This finding indicates that the disease onset affected the leisure practices, in their different content, and also the practice of leisure physical activities or of other purposes. So, before the disease, more than half of the patients practiced physical activities, including both sports and walking, however, after the disease onset, only one in four patients performed physical activities. This represents a decrease of almost $30 \%$ of patients in this practice and corroborates the results of Kim et al. [20], who pointed out that patients with LE are little engaged in physical activities.

We conclude that there is a double problem: the patients were not even practicing enough physical activities and not engaged in leisure activities, whether leisure physical-sports or sedentary leisure activities. It is worth remembering here that the practice of physical activity can improve aerobic metabolism, muscle strength, fatigue and chronic fatigue decrease, and depression as already shown in patients with Systemic LE [41], [42].

The benefits of physical activity practice in the immune system of patients with autoimmune diseases are already established in the literature [43]. Even if performed spontaneously and without periodicity, it can bring benefits, although studies are necessary to confirm this hypothesis. It is also noteworthy that, in cases of dermatomyositis, it is desirable to improve physical capacities, such as strength, without increasing serum levels of enzymes and with aerobic training, as such patients may have impaired both function muscle and cardiorespiratory fitness [44]-[46]. For this, it is necessary to practice supervised physical activities at fixed periodicity as well as to investigate the contribution the leisure physical-sports practice can bring, that is, sports activities for pleasure and with no predetermined schedules.

The tendency towards a sedentary lifestyle brings losses predicted by Finlay [3], [9] and still lack actions to modify this panorama. As the study by Ahmed et al. [16], clarifications about this practice and periodic reassessments about its performance could help to reduce the disease manifestation and the consequent improvement in QoL.

However, for a direct intervention to be carried out in the search for improvements in leisure practice, QoL and reduction of disease symptoms, it is necessary that the different aspects of QoL are reported in the studies and not only to consider QoL good or not, according to the score attributed in the use of questionnaires such as the DLQI.
It is necessary that studies on the QoL of such patients start to pay attention to leisure practice, included in the DLQI questionnaire, specifically created for these purposes. The simple scoring of these items, without discussing their importance and without setting goals that make these people's leisure practices feasible, may not fully act in improving these patients' QoL, disregarding the right that every human being must practice them.

Scholars on leisure should pay attention to this part of the population, and new studies must be carried out, as to verify more accurately the reasons that lead these patients not to practice leisure, in order to assist in the elaboration of public policies so that this practice can be feasible. For this, an interdisciplinary effort is required to present proposals to minimize the reported difficulties.

There is also a need for guidance to these patients regarding the risks of physical inactivity and the benefits of leisure and the different possibilities of choice.

\section{CONCLUSION}

In general, the practice of leisure among patients with DCTD is low and little varied. The variability of leisure content was associated with education. There are indications that the clinical condition influences both leisure activities and the variability of this practice. The most reported content was virtual and manual leisure. There were no reports of tourist activities. Practices related to physical-sports leisure (sports activities in free time without supervision) were not reported; however, before the disease onset, patients mentioned practicing physical activities such as soccer, basketball, volleyball and cycling, without supervision, which did not occur after the disease onset. The percentage of practitioners of sports activities was much lower than that of the Brazilian population.

There is a need for guidance to these patients regarding the practice of leisure, so that they can make choices and vary the types of activity practiced, as well as more studies to support actions that can encourage and facilitate the leisure practices of patients with DCTD, deepening in terms of leisure in relation to QoL.

\section{ACKNOWLEDGMENT}

The authors thank Coordenação de Aperfeiçoamento de Pessoal de Nível Superior - CAPES; Conselho Nacional de Desenvolvimento Científico e Tecnológico - CNP for financial support and Espaço da Escrita - Pró-Reitoria de Pesquisa - UNICAMP - for the language services provided.

\section{REFERENCES}

[1] Organização Das Nações Unidas (ONU). Assembleia Geral das Nações Unidas e Comitê de Redação da Declaração Universal dos Direitos Humanos. Declaração Universal dos Direitos Humanos. 2009. Available: https://nacoesunidas.org/wpcontent/uploads/2018/10/DUDH.pdf.

[2] Brasil. Constituição da República Federativa do Brasil de 1988. Available:

http://www.planalto.gov.br/ccivil_03/constituicao/constituicao.htm.

[3] A. Y. Finlay, and G. K. Khan, "Dermatology Life Quality Index (DLQI) - a simple practical measure for routine clinical use," Clinical and experimental dermatology, vol. 19, no. 3, pp. 210-216, 1994. 
[4] C. S. Tejada, R. A. Mendoza-Sassi, H. L. A. Junior, P. N. Figueiredo, and V. F. S. Tejada, "Impact on the quality of life of dermatological patients in Southern Brazil," An Bras Dermatol, v. 86, n. 6, p. 1113 $1121,2011$.

[5] R. A. T. Torres, R. F. Magalhães, and P. E. N. F. Velho, "Comparison of quality of life questionnaires and their correlation with the clinical course of patients with psoriasis" An Bras Dermatol. vol. 86, no. 1, pp. 45-49, 2011.

[6] P. L. Mattei, K. C. Corey, and A. B. Kimball, "Psoriasis Area Severity Index (PASI) and the Dermatology Life Quality Index (DLQI): the correlation between disease severity and psychological burden in patients treated with biological therapies," J Eur Acad Dermatol Venereol, vol. 28, no. 3, pp. 333-337, 2014.

[7] M. A. Gupta, and A. K. Gupta, "Age and gender differences in the impact of psoriasis on quality of life," Int J Dermatol, vol. 34, p. 700 703, 1995.

[8] K. Ongenae, N. Van Geel, S. De Schepper, and J. M. Naeyaert, "Effect of vitiligo on self-reported health-related quality of life," $\mathrm{Br}$ Dermatol, vol. 152, no. 6, pp. 1165-1172, 2005.

[9] A. Y. Finlay, "Quality of life índices," Indian J Dermatol Venereol Leprol, vol. 70, no. 3, pp. 143-148, 2004.

[10] A. Langenbruch, M. A. Radtke, M. Gutknecht, and M. Augustin, "Does the Dermatology Life Quality Index (DLQI) underestimate the diseasespecific burden of psoriasis patients?," J Eur Acad Dermatol Venereol, vol. 33, no. 1, pp. 123-127, 2019.

[11] A. Mohta et al, "Evaluation of quality of life and psychological implications in patients with rosacea using dermatology life quality index (DLQI) and the hospital anxiety and depression scale (HADS)," Int J Med Biomed Sci, vol. 4, no. 3, 2020.

[12] P. R. Martins, T. Skare, T. A. Ferrari, A. P. Silva, and B. F. Alessio, "Comparative analysis of the quality of life of patients with discoid lupus erythematosus and systemic lupus erythematosus with skin injuries," An Bras Dermatol, vol. 87, no. 2, pp. 326-328, 2012.

[13] S. Méndez-Flores, R. Orozco-Topete, P. Bermúdez-Bermejo, and G Hernández-Molina, "Pain and pruritus in cutaneous lupus: their association with dermatologic quality of life and disease activity," Clin Exp Rheumatol, vol. 31, no. 6, pp. 940-942, 2013.

[14] A. Batalla, I. García-doval, G. Peón, and C. De La Torre, "A qualityof-life study of cutaneous lupus erythematosus," Actas Dermosifiliogr, vol. 104, no. 9, pp. 800-806, 2013.

[15] A. P. Fernandez, "Connective Tissue Disease," Dermatol Clin, vol. 37, pp. 37-48, 2019.

[16] S. Ahmed et al. "Evaluating important change in cutaneous disease activity as an efficacy measure for clinical trials in dermatomyositis," Br J Dermatol, vol. 182, no. 4, pp. 949-954, 2020.

[17] L. G. Rider et al, "Measures of adult and juvenile dermatomyositis, polymyositis, and inclusion body myositis: Physician and Patient/Parent Global Activity, Manual Muscle Testing (MMT), Health Assessment Questionnaire (HAQ)/Childhood Health Assessment Questionnaire (C-HAQ), Childhood Myositis Assessment Scale (CMAS), Myositis Disease Activity Assessment Tool (MDAAT), Disease Activity Score (DAS), Short Form 36 (SF-36), Child Health Questionnaire (CHQ), physician global damage, Myositis Damage Index (MDI), Quantitative Muscle Testing (QMT), Myositi Functional Index-2 (FI-2), Myositis Activities Profile (MAP), Inclusion Body Myositis Functional Rating Scale (IBMFRS), Cutaneous Dermatomyositis Disease Area and Severity Index (CDASI), Cutaneous Assessment Tool (CAT), Dermatomyositis Skin Severity Index (DSSI), Skindex, and Dermatology Life Quality Index (DLQI)," Arthritis Care Res, vol. 63, no. 11, pp 118-157, 2011.

[18] J. L. Hundley et al, "Cutaneous symptoms of dermatomyositis significantly impact patients' quality of life," J Am Acad Dermatol, vol. 54, no. 2, pp. 217-220, 2006.

[19] R. Goreshi et al, "Quality of life in dermatomyositis,". J. Am Acad Dermatol, vol. 65, no. 6, pp. 1107-1116, 2011.

[20] S.K. Kim, J.Y. Choe, and S.S. Lee, "Self-Reported Physical Activity Is Associated with Lupus Nephritis in Systemic Lupus Erythematosus: Data from KORean Lupus Network (KORNET) Registry," Yonsei Med J, vol. 59, no. 7, pp. 857, 2018.

[21] D. P. E. Margiotta et al, "Physical activity and sedentary behavior in patients with systemic lupus erythematosus," PloS one, vol. 13, no. 3 , 2018.

[22] J. Dumazedier, Lazer e cultura popular, São Paulo: Perspectiva, 1976.

[23] R. Requixa. Sugestões de diretrizes para uma política nacional de lazer. São Paulo, 1980.

[24] D. A. M. Silva et al, A importância da recreação e do lazer. Brasília: Ideal, 2011.

[25] N. Almeida Filho. O que é saúde, Rio de Janeiro: Fiocruz, 2018.

[26] N. C. Marcellino, Estudos do lazer: uma introdução, Campinas: Autores Associados, 1996.
[27] C. A. Souza et al, "Prevalence of leisure-time physical activity and associated factors: a population-based study in São Paulo, Brazil, 2008 2009," Cad. Saúde Pública, vol. 29, no. 2, 2013.

[28] K. J. Roulston, Open-ended question in Given, L.M (ed). The Sage Encyclopedia of qualitatives reseach methods. California: Sage, 2008, pp.82-83.

[29] V. Braun, "The online survey as a qualitative research tool," Int. J. Soc. Res. Methodol. 2020.

[30] L. O. L. Camargo, O que é lazer. São Paulo: Brasiliense, 1986.

[31] G. M. Schwartz, "O conteúdo virtual do lazer: Contemporizando Dumazedier," Licere, vol. 6, no. 2, pp. 23-31, 2003.

[32] D. Finkel, R. Andel, and N. L. Pedersen, "Gender Differences in Longitudinal Trajectories of Change in Physical, Social, and Cognitive/Sedentary Leisure Activities," J Gerontol B Psychol Sci Soc Sci, vol. 73, no. 8, pp. 1491-1500, 2018.

[33] L. T. Nicholson, and A. Haemel, "Outcome measures in dermatomyositis: quality of life and the patient perspective," The British journal of dermatology, vol. 182, no. 4, pp. 830-831, 2020.

[34] M. Cavallaro et al, "Stroke and Systemic Lupus Erythematosus: A Review," Rheumatology, pp. 100-107, 2018

[35] S. D. Mathias et al, "Patient experience in systemic lupus erythematosus: development of novel patient-reported symptom and patient-reported impact measures," Journal of patient-reported outcomes, vol. 2, no. 1, pp. 11, 2018.

[36] A. J. Pinto et al, "Reduced aerobic capacity and quality of life in physically inactive patients with systemic lupus erythematosus with mild or inactive disease," Arthritis Care Res, vol. 68, no. 12, pp. 1780 1786, 2016.

[37] L. Zhang et al, "Prevalence of depression and anxiety in systemic lupus erythematosus: a systematic review and meta-analysis," BMC psychiatry, vol. 17, no. 1, pp. 70, 2017.

[38] Q. Zhao et al, “As correlações de estado psicológico, qualidade de vida autoestima, suporte social e distúrbio da imagem corporal em pacientes chineses com lúpus eritematoso sistêmico," Psicologia, saúde medicina, vol. 23, no. 7, pp. 779-787, 2018

[39] G. I. Mielke, "Diferenças regionais e fatores associados à prática de atividade física no lazer no Brasil: resultados da Pesquisa Nacional de Saúde-2013," Rev Bras Epidemiol, vol. 18, no. 2, pp. 158-169, 2015.

[40] M. Droomers, C. T. M. Schrijvers, and J. P. Mackenbach, "Educational level and decreases in leisure time physical activity: predictors from the longitudinal GLOBE study," J Epidemiol Community Health, vol. 55, no. 8 , pp. 562-568, 2001

[41] T. I. R. Póvoa, "Lupus eritematoso sistémico, ejercicio físico y calidad de vida. Artículo de revisión," Rev Digital, no. 144, 2010.

[42] T. O'dwyer, L. Durcan, and F. Wilson, "Exercise and physical activity in systemic lupus erythematosus: a systematic review with metaanalyses. In: Seminars in arthritis and rheumatism," WB Saunders, pp. 204-215, 2017

[43] K. Sharif et al, "Physical activity and autoimmune diseases: Get moving and manage the disease," Autoimmunity reviews, vol. 17, no. 1 , pp. 53-72, 2018 .

[44] A. Escalante, L. Miller, and T. D. Beardmore, "Resistive exercise in the rehabilitation of polymyositis/dermatomyositis," 1993.

[45] J. E. Hicks, F. miller, P. Plotz, T. H. Chen, and L. Gerber, "Isometric exercise increases strength and does not produce sustained creatinine phosphokinase increases in a patient with polymyositis," J Rheumatol, vol. 20, no. 8, pp. 1399-1401, 1993.

[46] G. F. Wiesinger et al, "Aerobic capacity in adult dermatomyositis/polymyositis patients and healthy controls," Arch Phys Med Rehabil, vol. 81, no. 1, pp. 1-5, 2000 